\title{
Production of transparent exopolymer particles (TEP) by phyto- and bacterioplankton
}

\author{
Uta Passow* \\ Marine Science Institute, University of California, Santa Barbara, California 93106, USA
}

\begin{abstract}
Transparent exopolymer particles (TEP) exist abundantly in oceans and lakes and have been found to play an important role in sedimentation and biochemical cycling of matter. However, the origin of these particles and the factors regulating their formation are not well understood. This study examined several strains of algae and bacteria with respect to their production of TEP or TEP precursors. The formation rate of TEP in batch cultures of algae varied widely between species, and interspecies variability among diatoms was as large as that among species belonging to different classes or even divisions. Species, growth phase and environmental factors acted in concert in determining the accumulation of TEP in algal cultures and no general rules or patterns could be derived. The concentration of TEP during the growth phase of algal batch cultures, mesocosm or natural phytoplankton blooms was a significant function of chlorophyll $a$, confirming the significance of phytoplankton for the formation of TEP. Experiments with 3 bacterial strains and a natural bacteria population indicated that bacteria are also able to generate TEP, but the role of bacterial derived TEP for in situ TEP concentrations remains unclear.
\end{abstract}

KEY WORDS: Transparent exopolymer particles $\cdot$ TEP $\cdot$ Exudation $\cdot$ Phytoplankton $\cdot$ Bacteria

\section{INTRODUCTION}

Many aquatic microorganisms generate large amounts of extracellular mucilage, especially when growth conditions deteriorate (Hoagland et al. 1993, Myklestad 1995). These exopolymer secretions can exist as tight capsules surrounding a cell or as loose slimes in no apparent association with any one cell (Decho 1990). One type of mucilage, the transparent exopolymer particles (TEP) have recently received increased attention. TEP exist as discrete particles rather than as dissolved substances, capsules or surface coatings (Alldredge et al. 1993) and their role in aquatic systems differs appreciably from the non-particulate forms of exopolymeric substances (EPS) because, as independent particles, they impact aggregation dynamics (Logan et al. 1995).

*Present address: Alfred-Wegener-Institut, 27570 Bremerhaven, Germany. E-mail: upassow@awi-bremerhaven.de
TEP exist abundantly in oceans and lakes (e.g. Alldredge et al. 1993, Grossart \& Simon 1997) and can reach several hundred $\mu \mathrm{m}$ in size, although the vast majority of particles are small (Passow \& Alldredge 1994, Mari \& Burd 1998). TEP are very surface-active and easily aggregate with themselves and other particles. Because TEP are an essential component of many types of marine and lake snow (Rieman 1989, Alldredge et al. 1993, Grossart \& Simon 1997), which represent the main vehicle for fast downward flux of organic matter (Fowler \& Knauer 1986), they play an important role in sedimentation of particulate matter (Passow et al. 2001). TEP also change the food web structure by aggregating nanometer-sized particles, making them available as a food source for larger zooplankton like euphausiids (Dilling et al. 1998, Passow \& Alldredge 1999, Prieto et al. 2001). TEP can form abiotically from colloidal substances released by phytoplankton (Passow 2000) and bacteria (Grossart 1999, Stoderegger \& Herndl 1999) or from disintegrat- 
ing Phaeocystis spp. colonies (Passow 2000), but the origin of TEP and the conditions leading to the release of TEP and their precursors are not well known and the bacterial contribution to TEP concentrations found in situ is not well understood.

The goal of this study was to investigate some of the factors leading to the release of TEP and their precursors. Several experiments were conducted with batch cultures of phytoplankton to test the hypothesis that the production rate of TEP is species-specific and that it depends both on the physiological state of cells and the environmental conditions. The relationship between TEP and chlorophyll $a$ in cultures was compared to that observed during mixed phytoplankton blooms grown in mesocosms. Furthermore, the production of TEP by bacteria was examined.

\section{MATERIALS AND METHODS}

Experimental set-ups. All phytoplankton cultures (non-axenic) were grown in batch culture in $f / 2$ media based on seawater (Guillard 1975) at $15^{\circ} \mathrm{C}$ and $100 \mu \mathrm{mol} \mathrm{m}{ }^{-2} \mathrm{~s}^{-1}$ light on a 10:14 h light:dark cycle. Seawater and media were autoclaved separately to prevent precipitation, as precipitate interferes with the enumeration of TEP. In some experiments nutrient concentrations were lowered to about $30 \%$ of the full concentration of $\mathrm{f} / 2$ media to avoid excess growth, which would lead to self-shading.

Expt 1-TEP in cultures of different species of phytoplankton: The first set of experiments was conducted to compare TEP concentration in cultures of different algal species. TEP was measured in 9 different phytoplankton cultures, including 6 diatom species (Chaetoceros sp., North Sea isolate; Melosira nummuloides, North Sea isolate; Nitzschia sp., Santa Barbara Channel isolate; Rhizosolenia calcaravis CCMP 1518; Stephanopyxis turris CCMP 815; Thalassiosira rotula, Meunier, North Sea isolate), 1 dinoflagellate (Gonyaulax polyedra, CCMP 406), 1 coccolithophorid (Emiliana huxleyi, non-calcifying strain, PML 92d) and a green alga (Tetraselmis suecia, North Sea isolate). Cell number, chl $a$ and colorimetric TEP concentration were determined every 2 to $3 \mathrm{~d}$ during the growth cycle of these species, but at least twice during the exponential and twice during the stationary phases. Values from each growth phase (exponential growth, stationary) were averaged. Slides for microscopical determinations of TEP were also prepared and investigated sporadically.

Expt 2-TEP during growth and stationary phase: A second series of experiments was conducted with Chaetoceros affinis, Nitzschia angularis and Thalassiosira weissflogii to investigate the changes in TEP concentration during different growth phases of diatoms in more detail. Cultures of all 3 species were grown in $\mathrm{f} / 2$ media where all 3 macronutrients $\left(\mathrm{NO}_{3}\right.$, $\mathrm{PO}_{4}$ and $\mathrm{Si}(\mathrm{OH})_{4}$ ) were reduced to $30 \%$. Cell numbers, chl $a$ and TEP (colorimetric) were determined daily during the growth and stationary phases.

The potential of abiotic TEP production was also estimated daily in the culture of Chaetoceros affinis as described in Passow (2000). Briefly, all TEP were removed by filtering an aliquot of the culture through $0.2 \mu \mathrm{m}$ polycarbonate filters (Poretics). Newly formed TEP were determined colorimetrically after $24 \mathrm{~h}$ of incubation in a Couette flocculator (volume: $1600 \mathrm{ml}$ ) at a shear of $24.9 \mathrm{~s}^{-1}$. It is assumed that the amount of newly formed TEP was related to the concentration of colloidal TEP precursors.

Expt 3-TEP concentration as a function of nutrient supply: A third set of experiments was conducted with cultures of Chaetoceros affinis to test the impact of $\mathrm{Si}(\mathrm{OH})_{4}$ and $\mathrm{PO}_{4}{ }^{3-}$ limitation on TEP production. In one treatment, the concentration of $\mathrm{PO}_{4}{ }^{3-}$ was reduced (5 $\mu \mathrm{M}$ vs $26 \mu \mathrm{M})$, in another the concentration of $\mathrm{Si}(\mathrm{OH})_{4}$ was reduced $(130 \mu \mathrm{M}$ vs $270 \mu \mathrm{M})$. As a comparison, 2 replicate cultures were grown in full $\mathrm{f} / 2$ media. Cell numbers, chl $a$, nutrient concentrations $\left(\mathrm{NO}_{3}, \mathrm{PO}_{4}{ }^{3-}\right.$ and $\left.\mathrm{Si}(\mathrm{OH})_{4}\right)$ and colorimetric TEP concentration were recorded daily in all cultures.

Expt 4-relationship between TEP and phytoplankton: Two mesocosm experiments were conducted to determine the relationship between TEP and chl a during non-diatom blooms, because a consistent relationship between TEP and chl a had been observed in batch cultures of diatoms and during diatom blooms (Passow \& Alldredge 1995b). Two blooms were grown in a mesocosm (1400 l) during October 1995 and April 1996. A similar mesocosm experiment was described by Alldredge et al. (1995). Briefly, seawater from a depth of $15 \mathrm{~m}$ was filtered through a sand filter and then inoculated with $50 \mathrm{l}$ of surface water from the Santa Barbara Channel. Nutrients were added initially $\left(\mathrm{NO}_{3}+\mathrm{NO}_{2}=\right.$ $\left.60 \mu \mathrm{M}, \mathrm{SiO}_{4}=50 \mu \mathrm{M}, \mathrm{PO}_{4}=5 \mu \mathrm{M}\right)$, the temperature remained constant at $12^{\circ} \mathrm{C}$ and a $14: 10 \mathrm{~h}$ light:dark regime was imposed. A propeller rotated slowly near the bottom of the tank. TEP and chl a concentration were measured daily. TEP concentration was measured colorimetrically. Unpreserved, intact colonies of Phaeocystis spp. do not stain when the colorimetric method is used to measure TEP (Passow \& Alldredge 1995a).

Expt 5-TEP production by different bacteria strains: Two experiments were conducted to investigate the production of TEP by 3 different strains of bacteria. Bacteria were isolated, cultured and provided by F. Azam. Two species of bacteria, SB1 and SB2, were isolated from seawater in the Santa Barbara Channel and 1 species, named Agg1, was isolated from aggre- 
gates collected by divers in the Santa Barbara Channel. TEP production by SB2 was investigated in the first bacterial experiment by adding $1 \mathrm{ml}$ of the SB2 culture to $10 \mathrm{ml} \mathrm{GF} / \mathrm{F}$-filtered seawater and sampling after $20 \mathrm{~h}$ in the dark. During the second bacterial experiment, SB1 and Agg1 were each added to GF/F filtered seawater and both treatments were sampled after $12 \mathrm{~h}$. One GF/F-filtered seawater control (no bacteria added) and an antibiotic control (bacteria + antibiotics) per treatment were incubated in parallel for each experiment. A mixture of ampicillin, chloroamphenicol and streptomycin was added to the antibiotic controls to achieve end concentrations of 5, 33 and $66 \mu \mathrm{g} \mathrm{ml}^{-1}$, respectively. TEP concentrations were determined initially and at the end of each experiment. TEP were enumerated microscopically.

Expt 6-TEP production by natural bacteria and by turbulence: This last experiment was performed to compare bacterial and abiotic production of TEP during different turbulence regimes. Six 11 bottles filled with $1.0 \mu \mathrm{m}$ prefiltered surface water collected in the Santa Barbara Channel during summer were incubated for $22 \mathrm{~h}$ at ambient temperature in the dark. The same mixture of antibiotics used in Expt 5 was added to 3 of the bottles to provide controls. One treatment and 1 control (without and with antibiotics, respectively) were exposed to laminar shear by incubation in a Couette device (Drapeau et al. 1994) at a shear rate of $8 \mathrm{~s}^{-1}$. A second set of bottles was bubbled with a simple aquarium pump and the third set remained static. TEP concentration was measured initially and at the end of the experiment in all treatments using the colorimetric method. Bacterial abundance was determined microscopically after staining with Acridine Orange and counting at a magnification of $800 \times$ (Kirchmann 1993).

Sample analysis. Cell numbers of diatoms were counted in Fuchs/Rosenthal chambers at a magnification of 10 to $32 \times$, depending on the size of the cells. At least 300 cells were counted in at least 6 replicate subsamples. Cell volumes were calculated from average length and width of cells assuming simple geometrical shapes (Edler 1979). Chl a was measured in triplicate from 0.5 to $10 \mathrm{ml}$ of sample, filtered on a $0.4 \mu \mathrm{m}$ polycarbonate filter (Poretics), using a Turner Model 111 fluorometer (Parsons et al. 1984). Nutrients $\left(\mathrm{NO}_{3}, \mathrm{PO}_{4}{ }^{3-}\right.$ and $\left.\mathrm{Si}(\mathrm{OH})_{4}\right)$ were analyzed in duplicate with an autoanalyzer (Johnson et al. 1985). TEP was measured colorimetrically in 4 to 6 replicate samples and calibrated with Gum Xanthan (Passow \& Alldredge 1995a) for Expts 1 to 4 and 6. Replicate TEP slides for microscopical enumeration were prepared according to Passow \& Alldredge (1994) by filtering 2 to $10 \mathrm{ml}$ depending on the TEP concentration. The volume needed for filtration was determined microscopically by enumerating TEP on 1 to 3 test slides prior to the production of permanent slides. TEP larger than
$5 \mu \mathrm{m}$ were counted in 8 size classes $(5-10,10-20$, $20-40, \ldots, 640-1280 \mu \mathrm{m}$ ) for Expt 5. About 100 to 200 particles were counted at a magnification of $200 \times$. The choice between the microscopical and the colorimetrical method to determine TEP depends on the information required. Microscopical enumeration is required when information on the size distribution of TEP is important, but as the sizing of odd-shaped particles and assumptions necessary for volume or area calculations are prone to error, the quantitative estimate is less reliable. The colorimetric method is preferable for quantitative estimates, but overestimates the amount of material present as individual particles, if organisms with stainable coatings are abundant (see Table 1 and Expt 5 for examples). Slides were prepared and checked when the colorimetric method was used to compensate for this disadvantage.

\section{RESULTS}

\section{Expt 1-TEP in cultures of different species of phytoplankton}

This experiment was conducted to study speciesspecific differences in the occurrence of TEP. The average amount of TEP in cultures and the average amount of TEP per cell varied, respectively, by 2 and 3 orders of magnitude between species (Table 1). The standing stock of TEP as measured colorimetrically was presumably overestimated for both Nitzschia species tested, as these species generated an Alcian Blue stainable cell coating. A light cell-surface coating was also observed for Rhizosolenia calcaravis, but free TEP were abundant.

Because cell sizes of the tested species differed appreciably, the amount of TEP was normalized to cell volume for interspecific comparison. The amount of TEP normalized to cell volume varied by only 1 order of magnitude between species or groups, in contrast to the idea that TEP are produced predominantly by diatoms (Table 1). Cell volume-normalized TEP concentrations were high for several diatoms, but some non-diatom species (e.g. the dinoflagellate Gonyaulax polydera and the green alga Tetraselmis suecia) generated comparable amounts of TEP. Cell volumenormalized TEP concentration was low during growth, but high at senescence of a non-calcifying strain of Emiliana huxleyi.

\section{Expt 2-TEP during growth and stationary phase}

Three experiments with Chaetoceros affinis, Nitzschia angularis and Thalassiosira weissflogii, respectively, were conducted to test the hypothesis that TEP are 
Table 1. Production of transparent exopolymer particles (TEP) by different phytoplankton species grown in batch cultures. Average of 2 to 3 measurements during growth and stationary phases, respectively. nd: no data; (): stainable, non-TEP material; NS: North Sea isolate, provided by U. Riebesell; SBC: isolated from the Santa Barbara Channel, off California, provided by M. Brzezinski; CCMP: Provasoli-Guillard National Center for Culture of Marine Phytoplankton; PML: Plymouth Marine Laboratory

\begin{tabular}{|c|c|c|c|c|c|c|c|c|}
\hline \multirow[t]{2}{*}{ Species } & \multirow{2}{*}{$\begin{array}{c}\text { Cell } \\
\text { volume } \\
\left(\mu \mathrm{m}^{3}\right)\end{array}$} & \multirow{2}{*}{\multicolumn{2}{|c|}{ 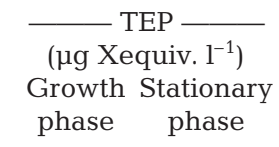 }} & \multirow{2}{*}{$\begin{array}{l}\text { Micro- } \\
\text { scopical } \\
\text { descrip- } \\
\text { tion }\end{array}$} & \multicolumn{2}{|c|}{$\begin{array}{c}- \text { TEP/cell vol. }-- \\
\left(10^{-9} \mu \mathrm{g} \text { Xequiv. } \mu \mathrm{m}^{-3}\right)\end{array}$} & \multicolumn{2}{|c|}{ 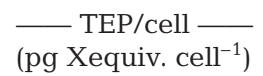 } \\
\hline & & & & & $\begin{array}{l}\text { Growth } \\
\text { phase }\end{array}$ & $\begin{array}{l}\text { Stationary } \\
\text { phase }\end{array}$ & $\begin{array}{l}\text { Growth } \\
\text { phase }\end{array}$ & $\begin{array}{l}\text { Stationary } \\
\text { phase }\end{array}$ \\
\hline Chaetoceros affinis, CCMP 159 & 1039 & 285 & 1107 & TEP & 22 & 15 & 23 & 16 \\
\hline Chaetoceros sp., NS isolate & 3500 & 893 & 2788 & TEP & 9 & 10 & 32 & 35 \\
\hline Melosira nummuloides, NS isolate & 4607 & 265 & 0 & TEP & 2 & 0 & 9 & 0 \\
\hline Nitzschia angularis & 1078 & $(230)$ & $(1625)$ & $\begin{array}{l}\text { Cells coated, } \\
\text { some TEP }\end{array}$ & $(1)$ & $(1)$ & $(1)$ & $(1)$ \\
\hline Nitzschia sp., isolate from SBC & 64 & $(161-3228)$ & 3) (2500) & Cells coated & $(25-31)$ & $(7)$ & $(2)$ & 0 \\
\hline $\begin{array}{l}\text { Rhizosolenia calcaravis, } \\
\text { CCMP } 1518\end{array}$ & 452390 & 353 & nd & $\begin{array}{c}\text { TEP, } \\
\text { some coating }\end{array}$ & 2 & nd & 904 & nd \\
\hline Stephanopyxis turris, CCMP 815 & 41693 & 2158 & 9300 & TEP & 26 & 26 & 1084 & 1084 \\
\hline Thalassiosira weissflogii & 995 & 1050 & 3100 & TEP & 3 & 4 & 3 & 4 \\
\hline $\begin{array}{l}\text { Thalassiosira rotula, Meunier, } \\
\text { NS isolate }\end{array}$ & 6429 & 196 & 600 & TEP & 4 & 4 & 23 & 2 \\
\hline $\begin{array}{l}\text { Emiliana huxleyi, non-calcifying } \\
\text { strain, PML 92d }\end{array}$ & 100 & 30 & 740 & TEP & 1 & 10 & 0 & 1 \\
\hline Tetraselmis suecia, NS isolates & 120 & 830 & 880 & TEP & 27 & 20 & 3 & 2 \\
\hline Gonyaulax polyedra, CCMP 406 & 65450 & 329 & nd & TEP & 20 & nd & 1309 & nd \\
\hline
\end{tabular}

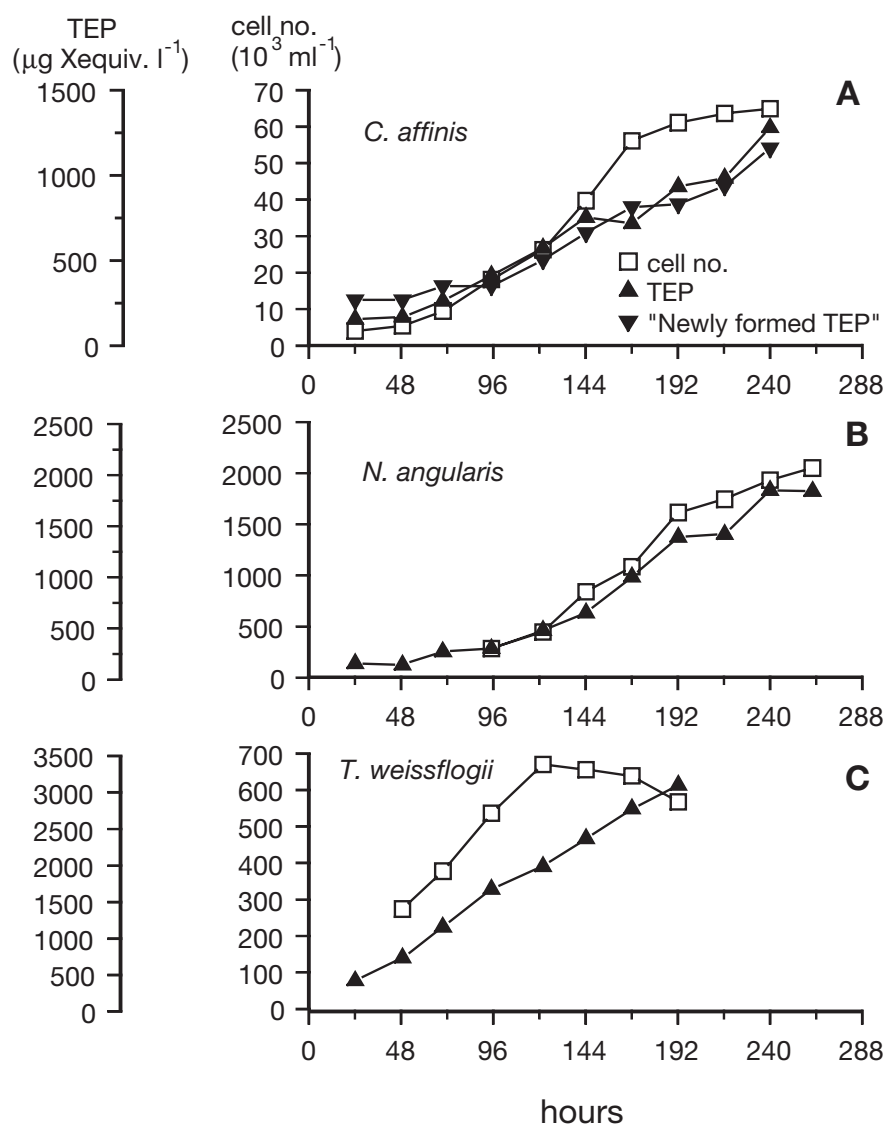

formed predominantly during senescence of phytoplankton cells. Concentrations of TEP were high in cultures of C. affinis and T. weissflogii and increased continuously during the growth and stationary phases (Fig. 1). Only small amounts of TEP were observed in the culture of $N$. angularis, but cells were coated with a stainable layer of Alcian Blue (see preceeding subsection).

Normalized TEP production and dynamics varied between species and changed with growth phase (Fig. 2A). Cultures of Chaetoceros affinis generated the largest amount of TEP relative to cell size. Normalized TEP concentration decreased during the growth phase of $C$. affinis (highly significant, $\mathrm{r}^{2}=0.95, \mathrm{df}=5$, $\mathrm{p}<0.001$ ) and increased again in the stationary phase (weakly significant; $\mathrm{r}^{2}=0.96, \mathrm{df}=2, \mathrm{p}<0.01$ ). Although the same trend was also visible in the $4 \mathrm{C}$. affinis cultures of Expt 3 (Fig. 2B), it was not statistically significant in any culture (low degree of freedom). The normalized TEP concentration in the culture of $T$. weiss-

Fig. 1. Expt 2: Cell numbers and transparent exopolymer particles (TEP) concentration in batch cultures of (A) Chaetoceros affinis, (B) Nitzschia angularis and (C) Thalassiosira weissflogii. In (A) the concentration of newly formed TEP after removal of TEP by filtration is also depicted. Note differences in ordinate scales 

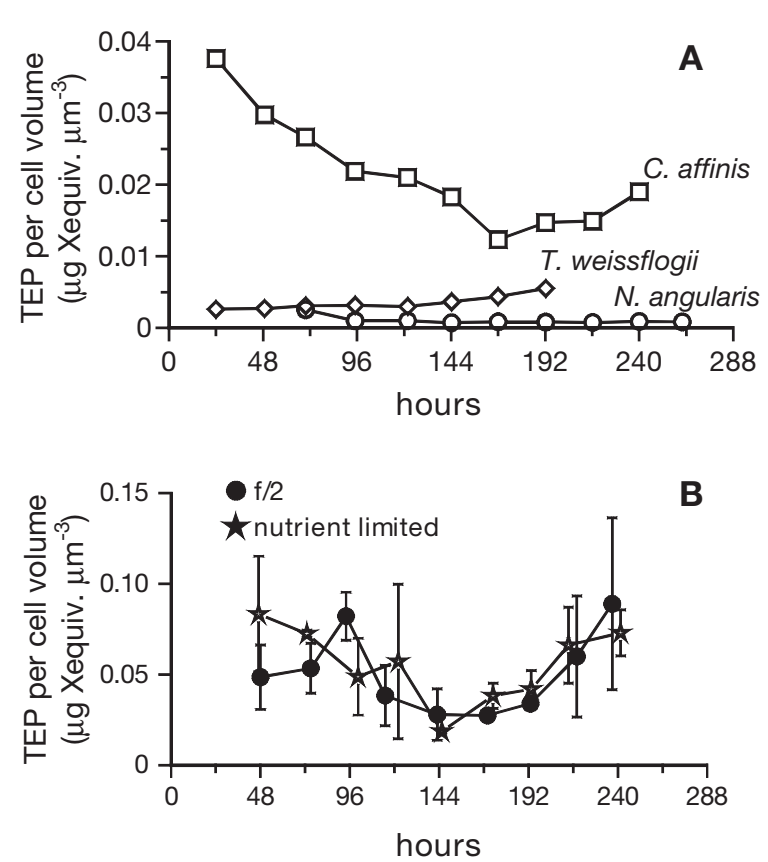

Fig. 2. TEP concentration normalized by cell volume for (A) batch cultures of Chaeotoceros affinis, Nitzschia angularis and Thalassiosira weissflogii (Expt 2) and (B) batch cultures of Chaeotoceros affinis grown under nutrient limitation or grown at full f/2 media (Expt 3). Standard deviations are for replicate cultures

flogii remained almost constant during growth. The slight increase during the stationary phase was not statistically significant. Normalized TEP concentration in the culture of $N$. angularis remained constant during the growth and stationary phases, reflecting the fact that alcian blue stained cell capsules in this culture.

The potential of the $0.2 \mu \mathrm{m}$-filtered culture media of Chaetoceros affinis to form TEP abiotically is assumed to be a function of the concentration of TEP precursors. During the whole experiment, the amount of new TEP formed within $24 \mathrm{~h}$ was similar to the amount of TEP originally removed (Fig. 1A), indicating that colloidal precursors of TEP and TEP themselves were in a dynamic equilibrium and that the concentration of TEP was small compared to the concentration of TEP precursors. Only if the concentration of TEP is small compared to their precursors, can TEP be fully replenished after their removal by filtration.

\section{Expt 3-TEP concentration as a function of nutrient supply}

This set of experiments was conducted with Chaetoceros affinis to test the hypothesis that phosphate or silicic acid limitation would increase the cell-normalized TEP concentration. After Day 6, silicic acid is
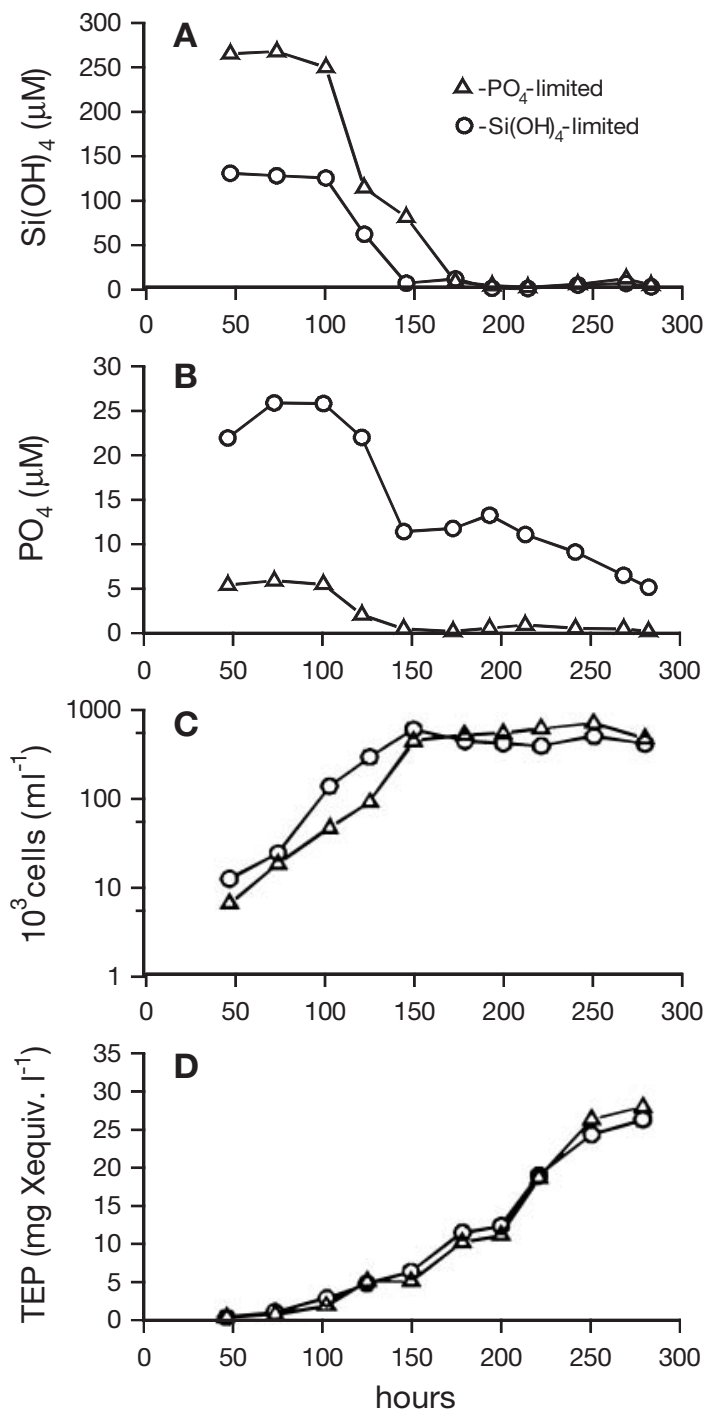

Fig. 3. Expt 3: Silicic acid concentration (A), phosphate concentration (B), cell number (C) and TEP concentration (D) in 2 batch cultures of Chaeotoceros affinis grown under $\mathrm{Si}(\mathrm{OH})_{4}$ and $\mathrm{PO}_{4}{ }^{3-}$ limitation, respectively

assumed to have limited growth in the treatment in which silicic acid was reduced $\left(\mathrm{Si}(\mathrm{OH})_{4}\right.$-limited), as growth stopped almost completely (growth rate $\ll 0.05 \mathrm{~d}^{-1}$ ) when the concentration of $\mathrm{Si}(\mathrm{OH})_{4}$ dropped to values $\leq 2 \mu \mathrm{M}$, whereas phosphate and nitrate concentrations remained high $(>12 \mu \mathrm{M}$ and $541 \mu \mathrm{M}$, respectively: Fig. 3A,B). Half-saturation constants $\left(K_{\mathrm{s}}\right)$ for $\mathrm{Si}(\mathrm{OH})_{4}$ uptake by individual diatoms range from 0.3 to $22 \mu \mathrm{M}$ (Nelson \& Brzezinski 1990).

Growth rates decreased appreciably in the treatment where $\mathrm{PO}_{4}{ }^{3-}$ was reduced $\left(\mathrm{PO}_{4}\right.$-limited) when the concentration of $\mathrm{PO}_{4}{ }^{3-}$ was $0.2 \mu \mathrm{M}$ and the $\mathrm{Si}(\mathrm{OH})_{4}$ concentration was $9 \mu \mathrm{M}$ on Day 6 (Fig. 3A,B). Growth continued at low levels (growth rate $=0.1 \mathrm{~d}^{-1}$ ) for $4 \mathrm{~d}$, but because $\mathrm{Si}(\mathrm{OH})_{4}$ never dropped below $5 \mu \mathrm{M}$, it is 
assumed that the growth in this culture was limited by availability of $\mathrm{PO}_{4}{ }^{3-}$. Half-saturation constants for $\mathrm{PO}_{4}{ }^{3-}$ uptake by oceanic diatoms are about $0.6 \mu \mathrm{M}$ (Perry 1976). The exact relationship between growth rate and external $\mathrm{PO}_{4}{ }^{3-}$ concentration is difficult to establish, but as long as no other nutrients limit growth rate, the internal $\mathrm{PO}_{4}{ }^{3-}$ pool remains small, and a linear relationship between $\mathrm{PO}_{4}{ }^{3-}$ and growth rate may be expected at low $\mathrm{PO}_{4}{ }^{3-}$ concentrations (Fuhs 1969).

Maximal cell numbers and TEP concentrations were similar in both cultures (Fig. 3C,D), and TEP concentration normalized by cell volume did not differ between treatments. The cell-volume-normalized TEP concentration was statistically the same as that in the 2 replicate cultures grown in full f/2 media (Fig. 2B), where self-shading diminished growth after Day 6 . The cell specific production of TEP increased in all treatments as growth rates decreased (in the stationary phase), independent of the limiting factors.

\section{Expt 4-relationship between TEP and phytoplankton}

Two phytoplankton blooms were conducted in mesocosms to investigate whether a relationship observed

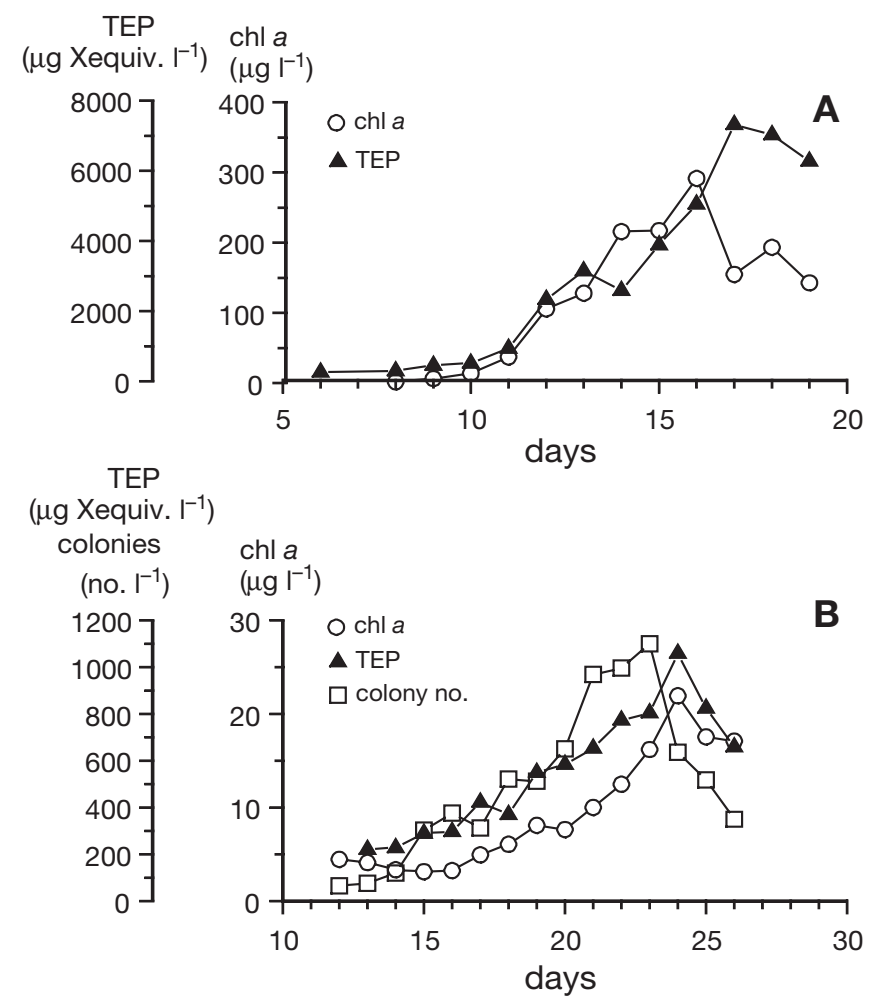

Fig. 4. Expt 4: Concentrations of (A) TEP and chl a during a mesocosm bloom dominated by dinoflagellates in October 1995 and (B) of TEP, chl $a$ and colony density during a mesocosm bloom dominated by Phaeocystis sp. in April 1996. Note differences in ordinate and abscissa scales between TEP and chl a from diatom cultures and natural diatom blooms could be extended to non-diatom blooms. The mesocosm bloom in October 1995 was dominated by naked dinoflagellates and phototrophic protists and reached a maximum chl a concentration of $291 \mu \mathrm{g} \mathrm{l}^{-1}$ at Day 16. TEP concentration increased simultaneously until Day 17, when the maximum concentration of $7320 \mu \mathrm{g}$ Xequiv. $\mathrm{l}^{-1}$ (Xanthan equivalents per liter) was reached (Fig. 4A). No aggregates were observed after the bloom peaked, but several days later whitish, detrital flocs appeared.

The mesocosm bloom in April 1996 was dominated by Phaeocystis sp., and colony density reached a maximal value of 1100 colonies $1^{-1}$ on Day 23. TEP concentration increased during the growth of the bloom, and both TEP and chl a concentration peaked on Day 24, at $1059 \mu \mathrm{g}$ and $22 \mu \mathrm{g}$ Xequiv. $\mathrm{l}^{-1}$, respectively (Fig. 4B). TEP continued to increase after the colony matrix began disintegrating (colony numbers decreased, chl a increased), but decreased thereafter when chl a declined. No aggregates formed during this bloom.

Data from natural blooms, mesocosm blooms and batch cultures all showed the same type of relationship between TEP and chl a. During the growth phase of phytoplankton the concentration of TEP as a function of chl a was, in all cases, best described (closest fit) by a power-law function of the type TEP $=\alpha(\mathrm{chl} a)^{\beta}$, where TEP and chl $a$ are given in $\mu$ g Xequiv. $1^{-1}$ and $\mu \mathrm{gchl}$ a $\mathrm{l}^{-1}$, respectively. This relationship appears to be universal for many types of blooms and the values for $\alpha$ and $\beta$ vary between blooms and species (Table 2).
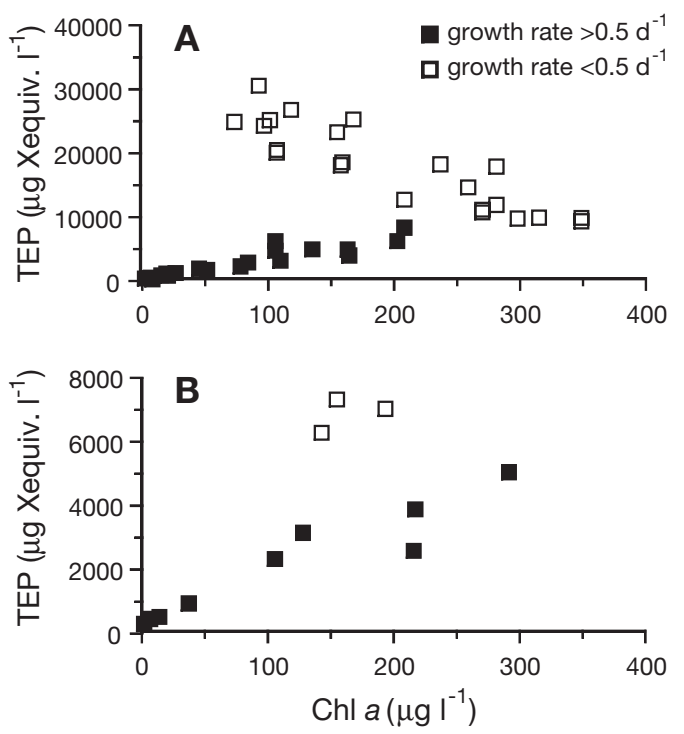

Fig. 5. TEP as a function of chl a (A) in 3 batch cultures of Chaeotoceros affinis grown under differing nutrient conditions $\left(y=134 x^{0.71}, r^{2}=0.92 \mathrm{n}=20\right.$; Expt 3, growth $\left.>0.5 \mathrm{~d}^{-1}\right)$, and (B) during a mesocosm bloom dominated by dinoflagellates $\left(y=163 x^{0.56}, r^{2}=0.95, n=9 ;\right.$ Expt 4$)$ 
Table 2. Relationship between TEP and chl a during growth phase (positive growth rates) of different blooms and cultures. $\mathrm{TEP}=\alpha(\mathrm{chl} a)^{\beta}$, in $\mu \mathrm{g}$ Xequiv. $\mathrm{l}^{-1}$ and in $\mu \mathrm{g}^{-1}$; nd $=$ no data

\begin{tabular}{|c|c|c|c|c|c|c|c|}
\hline Species & Sampling site & $\alpha$ & $\beta$ & $\mathrm{n}$ & $\mathrm{r}^{2}$ & $\mathrm{p}$ & Source \\
\hline Chaetoceros affinis & Batch culture & 152 & 1.06 & 6 & 0.94 & $<0.001$ & This study: Expt 2 \\
\hline Thalassiosira weissflogii & Batch culture & 221 & 0.68 & 5 & 0.94 & $<0.002$ & This study: Expt 2 \\
\hline Nitzschia angularis & Batch culture & 204 & 0.46 & 12 & 0.91 & $<0.001$ & This study: Expt 2 \\
\hline Chaetoceros affinis ${ }^{\mathrm{a}}$ & Batchculture & 106 & 0.88 & 42 & 0.71 & $<0.001$ & This study: Expt 3 \\
\hline Chaetoceros neogracile ${ }^{b}$ & Batch culture & nd & 0.96 & 14 & 0.90 & $<0.001$ & Calculated from Waite et al. (1995) \\
\hline Mixed diatoms ${ }^{c}$ & Mesocosm 93 & nd & 0.33 & 9 & 0.89 & $<0.001$ & Calculated from Passow \& Alldredge (1995b) \\
\hline Dinoflagellates & Mesocosm Oct 95 & 163 & 0.56 & 9 & 0.95 & $<0.001$ & This study: Expt 4 \\
\hline Phaeocystis sp. & Mesocosm Apr 96 & 106 & 0.76 & 12 & 0.91 & $<0.001$ & This study: Expt 4 \\
\hline Phaeocystis antarctica & Ross Sea & 1 & 3.63 & 71 & 0.66 & $<0.001$ & (Hong et al. 1997) \\
\hline Diatoms $^{\mathrm{d}}$ & East Sound Apr 94 & 176 & 0.45 & 8 & 0.61 & $<0.1$ & Calculated from Kiørboe et al. (1996) \\
\hline Mixed diatoms ${ }^{\mathrm{e}}$ & Baltic Sea & 282 & 0.33 & 48 & 0.62 & $<0.001$ & Calculated from Engel (2000) \\
\hline \multicolumn{4}{|c|}{$\begin{array}{l}\text { a Combined data from all cultures of Expt } 3 \\
{ }^{b} \text { Calculations based on cell number not chl a } \\
{ }^{c} \text { TEP measured as alginic acid equiv. }\end{array}$} & & \multicolumn{3}{|c|}{$\begin{array}{l}\mathrm{d} \text { Thalassiosira mendiolana dominated } \\
{ }^{\mathrm{e}} \text { Detonula confervacae dominated }\end{array}$} \\
\hline
\end{tabular}

The relationships were highly significant in all cases, with the exception of the bloom in East Sound. Values for $\beta$ were $\leq 1$, except during a natural bloom of Phaeocystis antarctica.

During the stationary and senescence phases the relationship between TEP and chl a changed. Data from the 3 Chaetoceros affinis cultures of Expt 3 suggest an inverse relationship after growth has ceased (growth rate $<0.5 \mathrm{~d}^{-1}$ : Fig. 5A). Because data collected during the senescent phase of mixed blooms (in situ or in mesocosms) comprised only 2 to 4 points each (Fig. 5B), no general relationship could be derived for this stage, although TEP concentration increased with decreasing chl a concentrations.

\section{Expt 5-TEP production by different bacterial strains}

The fifth set of experiments was conducted to investigate the potential of bacteria to generate TEP. Significant amounts of TEP were generated in seawater treatments enriched with Bacteria Strains SB1 and SB2: The abundance of TEP between 5 and $100 \mu \mathrm{m}$ had increased after 12 and $20 \mathrm{~h}$ in experiments with SB1 and SB2, respectively. No significant difference in TEP abundance was observed for large TEP > $125 \mu \mathrm{m}$ (Fig. 6). No TEP was generated in treatments enriched with Bacteria Strain Agg1, the seawater control or any of the control treatments to which antibiotics had been added. Some capsules formed around bacteria cells of Agg1, but no TEP formed. As no TEP appeared in the treatment enriched with Agg1, it can be assumed that the production of TEP by indigenous bacteria was negligible even after the addition of dissolved organic carbon (DOC) to the culture media, and that TEP in treatments enriched with SB1 and SB2 was predominately generated by these strains.

\section{Expt 6-TEP production by natural bacteria and by turbulence}

This last experiment was conducted to compare bacterial production of TEP under different turbulence
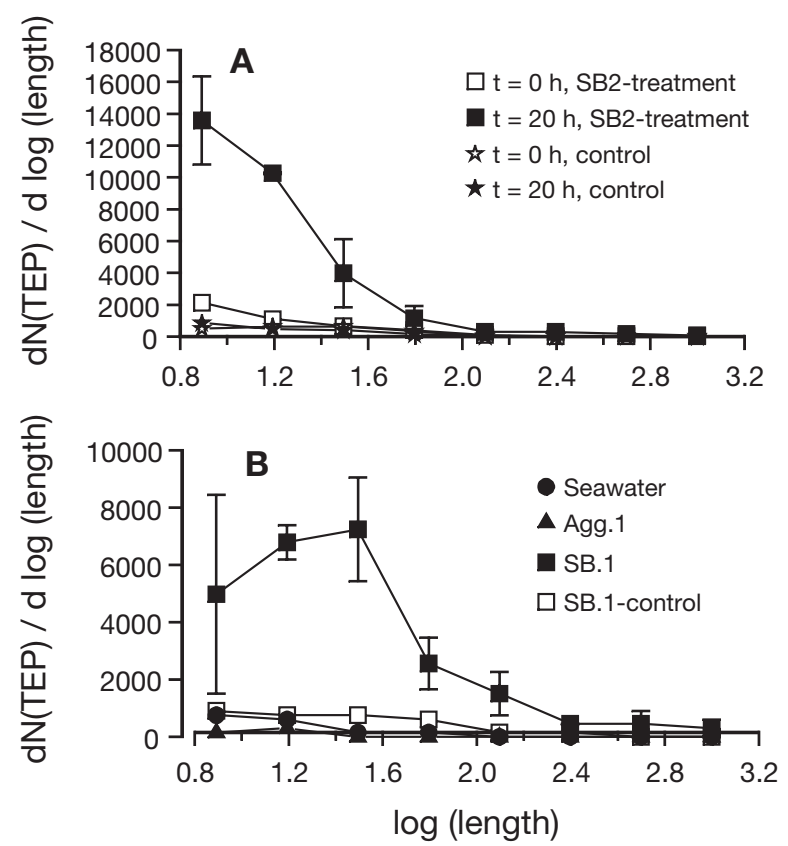

Fig. 6. Expt 5: Size-frequency distribution of TEP (length in $\mu \mathrm{m}$ ) initially and after $20 \mathrm{~h}$ in the treatment with Bacteria Strain SB2 and the respective antibiotic control (A), and in treatments with Strains Agg1 and SB1, as well as the seawater and the SB1-antibiotic control after $12 \mathrm{~h}$ (B). Data from the Agg1 antibiotic control and data on initial concentrations are not shown, because they were not significantly different from the Agg1 or seawater treatments. Error bars denote standard deviations of replicate counts and were sometimes too small to be shown 
regimes. Bacterial concentrations were very low in all antibiotic controls (Table 3). TEP concentrations in the bubbled and the static antibiotic controls were not statistically different (Student's $t$-test) from zero, suggesting that no significant amount of TEP was generated spontaneously (static treatment) or was due to surface coagulation (bubbled treatment). In contrast, TEP concentration was elevated in the antibiotic control exposed to shear ( $t$-test, $\mathrm{p}=0.01$ ), confirming prior studies that TEP can be generated very effectively by high shear rates (Passow 2000).

In all treatments, appreciably more TEP was generated in the absence of antibiotics compared to the respective antibiotic controls $(t$-test, $p=0.01)$, suggesting that the indigenous bacteria generated TEP (Table 3). Concentrations of TEP and of bacterial abundances in treatments exposed to bubbling or shear were both significantly higher ( $t$-test, $p=0.01)$ than in the respective static treatment (Table 3).

Assuming that the abiotic formation of TEP from polymers due to surface coagulation or shear was not impacted by the presence of bacteria, and because no TEP was generated abiotically, TEP in the bubbled treatment must have been generated by bacteria. In the shear treatment, $11 \%$ of the amount of TEP generated was presumably formed abiotically, whereas the remaining TEP formation was associated with the presence of actively metabolizing bacteria.

\section{DISCUSSION}

Patterns of photosynthetic extracelluar release (PER) and factors impacting such exudation have been studied extensively during the last decades (e.g. Myklestad et al. 1972, Berman \& Holm-Hansen 1974, Hellebust 1974, Myklestad 1974, 1995, Sharp 1977, Mague et al. 1980, Fogg 1983, Lancelot 1983, Decho 1990). Nevertheless, general rules regarding PER are difficult to formulate, because the patterns of exudation, the total quantity and the factors enhancing release are highly species-specific (Decho 1990, Penna et al. 1999). Few studies have actually investigated conditions impacting the release of TEP precursors.

Although many marine organisms release polysaccharides into the water (Decho 1990), most marine studies on TEP production have focused on diatoms or Phaeocystis spp. High concentrations of TEP have predominantly been observed during blooms dominated by diatoms (Passow \& Alldredge 1994, Passow et al. 1995, 2001, Mari \& Kiørboe 1996, Mari \& Burd 1998) or Phaeocystis spp. (Riebesell et al. 1995, Hong et al. 1997).
The coexisting diatom populations were held responsible for elevated TEP concentrations observed during 2 dinoflagellate blooms (Passow \& Alldredge 1994, Alldredge et al. 1998). Investigations of TEP in lakes suggest, however, that species of many other phytoplankton groups generate TEP (Grossart \& Simon 1997, Grossart et al. 1998, Berman \& Viner-Mozzini 2001).

The experiments with different phytoplankton species illustrated that variability in TEP production between diatoms was as high as that between species from different algal groups. As cultures were not axenic, the concentration of TEP was determined both by phytoplankton and bacteria, but the good correlation between TEP and phytoplankton suggests, that predominantly phytoplankton determine TEP concentration. Earlier batch culture experiments have already suggested that differences in TEP production exist between different diatom species. The production of TEP by Chaetoceros neogracile was higher than that by Thalassiosira weissflogii or Nitzschia angularis (Passow \& Alldredge 1994). Normalized production of TEP by $C$. affinis tended to be higher than that of the diatom Skeletonema costatum or the flagellate Rhodomonas baltica (Kiørboe \& Hansen 1993). The amount of TEP generated by $S$. costatum during growth was in fact negligible and TEP was generated only during late senescence (Kiørboe \& Hansen 1993). S. costatum is also known for its extremely low production of total extracellular polysaccharides. Extracellular polysaccharides of $S$. costatum and $C$. curvisetus contribute 1 and $56 \%$, respectively, to total cellular and extracellular carbohydrates (Myklestad 1995), but the reasons for these differences are obscure.

A direct comparison between the present study and the above mentioned studies is impossible, as TEP was measured microscopically in the latter but colorimetrically in the present study. The experiments presented here confirm, however, differences in the production of TEP between species and show that not only diatoms, but also members of many other phytoplankton groups, e.g. dinoflagellates, green algae and coccolithophorids, can generate TEP abundantly. The production of TEP and the timing of maximal release are both species-specific characteristics. The ecological reasons for the production of TEP precursors may differ for different phytoplankton groups. The acidic polysaccharides, 
which are released into the water by calcifying and non-calcifying strains of coccolithophorids, for example, perform regulatory functions in the calcifying process (de Jong et al. 1979).

It is widely accepted that extracellular release by phytoplankton is high during the stationary phase of growth, but it is controversial under which conditions actively growing cells release significant amounts of material (Hellebust 1974, Sharp 1977, Mague et al. 1980, Penna et al. 1999). Similarly, TEP production also depended on growth phase and varied between species in the present study. Depending on species, TEP concentration normalized to cell concentration was elevated, the same or lower during the growth phase compared to the stationary phase (Table 1). Expt 2 investigated the dynamics of TEP production during growth in more detail. TEP accumulated during the exponential and the stationary phase in all 3 cultures tested, verifying that TEP precursors can be released by actively growing cells and that the release of these substances is not only a direct consequence of environmental stress or cell death (Fig. 1). During the growth and stationary phases, TEP precursors seem to be released actively or by passive permeation (leakage), whereas cell death and lysis are increasingly important for the formation of TEP by senescent cells (Baldi et al. 1997).

Environmental conditions, especially nutrient limitation, also alter PER (Myklestad et al. 1972, Fogg 1983, Lancelot 1983, Decho 1990, Staats et al. 2000). The quantitative and qualitative effects of nutrient limitation on patterns of excretion are species-specific, and the phase of growth during which limitation occurs also affects the rate of release in different ways (Myklestad 1974, 1995, Penna et al. 1999). The issue is further complicated by the fact that release patterns differ for different substances excreted (Obernosterer \& Herndl 1995). Chaetoceros affinis batch cultures grown under severe $\mathrm{PO}_{4}{ }^{3-}$ limitation $(\mathrm{N}: \mathrm{P}=100)$ yielded much higher PER than those grown under a more balanced nutrient supply ( $\mathrm{N}: \mathrm{P}=16)$, but the release of polymeric carbohydrates did not differ significantly between growth regimes (Obernosterer \& Herndl 1995). The specific release of polymeric carbohydrates normalized to chl a was significantly elevated during the stationary growth phase (Obernosterer \& Herndl 1995). The response to nutrient limitation also depends on the species, and the rate of extracellular polysaccharide production in a culture of a different Chaetoceros sp. grown under P- or Si- limitation (N:P = 100; N:Si = 5) was negligible during all growth phases (Penna et al. 1999). In the experiments presented here, the production of TEP or the cell-volume normalized TEP-production did not differ when $C$. affinis was grown under sili$\operatorname{cic}$ acid $(\mathrm{N}: \mathrm{Si}=4)$ or phosphate limitation $(\mathrm{N}: \mathrm{P}=103)$ compared to growth under more balanced conditions $(\mathrm{N}: \mathrm{Si}=2 ; \mathrm{N}: \mathrm{P}=20$ : Fig. 2). Normalized TEP production increased as growth rate decreased in the stationary phase, independent of the factor triggering a reduction in growth rate (nutrient limitation, self-shading).

The results of Expts 1 to 3 suggest that the production dynamics of TEP are highly species-specific and that they are not always the same as those of total released polysaccharides. Other environmental conditions have also been shown to affect TEP production. Light intensity affected the amount of TEP generated by Phaeocystis antarctica (Hong et al. 1997). Carbon dioxide concentrations impacted the production of TEP during a bloom dominated by diatoms and colonial cyanobacteria (Engel 2002).

Its dependence on environmental conditions suggests that the production of TEP may be a function of the growth rate of cells. Exudation of organic matter by phytoplankton is often a function of growth rate (Myklestad et al. 1989). During experiments conducted with Chaetoceros neogracile, normalized TEP concentration was in fact positively correlated with growth rate (Waite et al. 1995) ${ }^{1}$. The experiments presented here for $C$. affinis at different nutrient concentrations (Expt 3) appear to confirm a correlation with growth rate, although the correlation was not statistically significant.

During the growth phase of phytoplankton, TEP concentration can be described as a function of chl a concentration (Table 2), suggesting the dominance of phytoplankton rather than bacteria in the production of TEP. Although different for every culture or bloom, this relationship was always highly significant, except in the case of a diatom bloom observed in East Sound, off Washington, USA. The TEP concentration during the bloom in East Sound was relatively low, possibly because the dominating Thalassiosira mendiolana generated very little TEP (Kiørboe et al. 1996), or possibly because the appendicularians removed TEP by their filtering activity.

During the majority of the blooms, the ratio between TEP and chl a concentration decreased during the progression of the bloom (i.e. $\beta<1$ ), implying either loss of TEP or a decrease in the cell-specific production rate of TEP as the blooms progressed and growth rates decreased. The Phaeocystis antarctica bloom in the Ross Sea represents the only exception, presumably because larger colonies were more common at high chl a concentrations and because the release of material by disintegrating colonies is more likely with large colonies than small colonies (Hong et al. 1997).

\footnotetext{
${ }^{1}$ Silicic acid concentration in the $25 \%$ Si treatment was $60 \mu \mathrm{M}$, not $6 \mu \mathrm{M}$ as stated erroneously in the cited paper
} 
Although the major source of TEP in the ocean is assumed to be phytoplankton-derived, the role of bacteria for the production of TEP is potentially too important to ignore. Bacteria are known to generate copious amounts of polysaccharides, both as free exopolymers or as capsules and films (e.g. Decho 1990, Cowen 1992, Costerton et al. 1995, Shibata et al. 1997). Metabolically active bacteria constantly renew their capsules and a significant fraction of the capsular material is continuously released into the ambient water (Heissenberger et al. 1996, Stoderegger \& Herndl 1998). These bacteria-derived exopolymers are thought to represent one source of TEP. The formation of TEP by a bacterial isolate and by a natural bacteria population has been shown (Grossart 1999, Stoderegger \& Herndl 1999). These data suggest, however, that only 1 to $2 \%$ of TEP found in situ is of bacterial origin (Stoderegger \& Herndl 1999). Another experiment with a natural bacteria population also suggested that bacteria produce TEP but that they were of minor importance for the formation of TEP in situ (Schuster \& Herndl 1995).

I have shown that an indigenous bacteria population was important in the production of TEP (Expt 6) and that 2 out of 3 bacterial isolates generated TEP (Expt 5). This data thus confirms that bacteria can contribute to the generation of TEP. One of the bacterial populations examined did not generate TEP under the prevailing conditions. The time interval of the experiment was possibly too short for these bacteria to release any measurable amounts of TEP into the water via their capsules, as proposed by Stoderegger \& Herndl (1998).

The size frequency distribution of TEP formed by SB2 (Fig. 6), which reflects an exponential decrease in particle abundance with increasing log size, is consistent with the formation of TEP from colloidal matter (Mari \& Kiørboe 1996, Mari \& Burd 1998). The low concentration of small particles in the treatment enriched with SB1 could be an artifact of counting; the large standard deviation in the small size classes supports this possibility. Alternatively the size distribution of TEP in SB1 may be dominated by aggregation of larger TEP (Passow \& Alldredge 1994), or reflect a different formation mechanism of TEP.

Although TEP can at times form spontaneously (Chin et al. 1998) or after stimultion by bubbling (Mopper et al. 1995, Passow 2000), only high shear rates caused the abiotic formation of TEP in Expt 6. Both shear and bubbling stimulated growth of bacteria appreciably (the estimated growth rates of bacteria in the static, bubbled and shear treatments were 2.5, 3.6 and $4.8 \mathrm{~d}^{-1}$, respectively). Enhanced bacterial growth due to bubbling has been attributed to the higher availability of DOC to bacteria after surface coagulation (Kepkay \& Johnson 1988, 1989). Higher bacterial uptake rates of macromolecules in stirred samples compared to static samples (Confer \& Logan 1991) may explain the elevated growth rates in sheared samples.

The measured specific production rate of TEP (TEP generated per bacteria) was fairly similar in all 3 treatments, suggesting that, over $24 \mathrm{~h}$, differences in the turbulence regime did not impact the abiotic coagulation of freshly released polymers. Either equilibrium conditions were achieved in all treatments in less than $24 \mathrm{~h}$ or, alternatively, bacteria generated TEP by a different mechanism, making differences in formation rates due to differences in the physical regime irrelevant. The simplest explanation of the data thus suggests that bacteria dominated the production of TEP and that the physical regime influenced the growth of bacteria, but not the formation of TEP. However, other explanations are possible if different processes cancelled each other out. The interactions between bacteria and TEP are complex (degradation, modification and production) and the presence of bacteria may have increased the abiotic formation of TEP by surface coagulation or shear.

The specific production rate of TEP by bacteria in all 3 treatments was very high, more than 1 order of magnitude higher than the average specific TEP production rate measured over a $10 \mathrm{~d}$ period of exponential growth in another study (Stoderegger \& Herndl 1999), and too high to be sustainable over longer time periods. Presumably the specific TEP production rate measured in experiment 6 represented a transient shortterm event. Possibly bacteria generate TEP without releasing TEP or precursors, by modifying organic substances present in the ambient seawater.

In situ and in most batch cultures, the production of TEP is presumably not a result of phytoplankton or bacterial activity alone, but of the interaction between bacteria and phytoplankton. Even in a simple system consisting of 1 diatom species and 1 bacterial isolate, the production of TEP is not predictable from individual production rates (Grossart 1999). Bacteria might be able to regulate the production of TEP by phytoplankton by stimulating the release of TEP precursors by phytoplankton. Bacterial hydrolysis of mucus from the surface of diatom cells may also enhance the formation of TEP (Smith et al. 1995), and bacteria may alter substances released by phytoplankton so that they qualify as TEP. Experiments presented here show that factors regulating the release of TEP or TEP precursors are complex. Predictions are further stymied by the fact that very little is known about loss processes of TEP. One experiment comparing an axenic with a non-axenic batch culture suggests that bacteria in batch cultures degrade TEP (Kiørboe \& Hansen 1993), making our estimates of TEP production in batch cultures conservative. However, in other experiments, TEP was more abundant in mixed than in axenic cultures (Grossart 1999). 


\section{CONCLUSIONS}

The release patterns of TEP by phytoplankton are different from those of bulk polysaccharides but similarly complex, with growth phase and species determining the impact of environmental factors. Within one species, growth rate, rather than specific environmental conditions, appears to regulate release of TEP and TEP precursors. The strong relationship between TEP and chl a observed during blooms and in batch cultures suggests that phytoplankton are a major source of TEP. Bacteria also generate TEP, although their qualitative contribution and the formation mechanisms of bacterially derived TEP are still awaiting discovery.

Acknowledgements. I thank Farooq Azam, Ulf Riebesell and Mark Brzezinski for providing algal and bacterial cultures and Kathy Schreier, Stephanie Oakes and Nikole Paulos for help with growing the cultures. The mesocosm experiments would not have been possible without Alice Alldredge, Patricija Mozetic and Paul Fowler. Thanks to Anja Engel for critically reading the manuscript. The Deutsche Forschungsgemeinschaft and US National Science Foundation funded this work.

\section{LITERATURE CITED}

Alldredge AL, Passow U, Logan BE (1993) The abundance and significance of a class of large, transparent organic particles in the ocean. Deep-Sea Res Part I 40:1131-1140

Alldredge AL, Gotschalk C, Passow U, Riebesell U (1995) Mass aggregation of diatom blooms: insights from a mesocosm study. Deep-Sea Res Part I 42:9-28

Alldredge AL, Passow U, Haddock SHD (1998) The characteristics and transparent exopolymer (TEP) content of marine snow formed from thecate dinoflagellates. J Plankton Res 20:393-406

Baldi F, Minacci A, Saliot A, Mejanelle L, Mozetic P, Turk V, Malej A (1997) Cell lysis and release of particulate polysaccharides in extensive marine mucilage assessed by lipid biomarkers and molecular probes. Mar Ecol Prog Ser 153:45-57

Berman T, Holm-Hansen O (1974) Release of photoassimilated carbon as dissolved organic matter by marine phytoplankton. Mar Biol 28:305-310

Berman T, Viner-Mozzini Y (2001) Abundance and characteristics of polysaccharide and proteinaceous particles in lake Kinneret. Aquat Microb Ecol 24:255-264

Chin WC, Orellana MV, Verdugo P (1998) Spontaneous assembly of marine dissolved organic matter into polymer gels. Nature 391:568-572

Confer DR, Logan BE (1991) Increased bacterial uptake of macromolecular substrates with fluid shear. Appl Environ Microbiol 57:3093-3100

Costerton JW, Lewandowski Z, Caldwell DE, Korber DR, Lappin-Scott HM (1995) Microbial biofilms. In: Annu Rev Microbiol, Annual Reviews Inc, Palo Alto, CA, p 711-745

Cowen, JP (1992) Morphological study of marine bacterial capsules: implications for marine aggregates. Mar Biol 114:85-95

De Jong E, Van Rens L, Werstbroek P (1979) Biocalcification by the marine algae Emiliania huxleyi (Lohmann) Kamptner. Eur J Biochem 99:559-567
Decho AW (1990) Microbial exopolymer secretions in ocean environments: their role(s) in food web and marine processes. Oceanogr Mar Biol Annu Rev 28:73-153

Dilling L, Wilson J, Steinberg D, Alldredge AL (1998) Feeding by the euphausiid Euphausia pacifica and the copepod Calanus pacificus on marine snow. Mar Ecol Prog Ser 170: 189-201

Drapeau DT, Dam HG, Grenier G (1994) An improved flocculator design for use in particle aggregation experiments. Limnol Oceanogr 39:723-729

Edler L (1979) Recommendations on methods for marine biological studies in the Baltic Sea: Phytoplankton and chlorophyll. Publ Balt Mar Biologists 55:1-38

Engel A (2000) The role of transparent exopolymer particles (TEP) in the increase in apparent particle stickiness (alpha) during the decline of a diatom bloom. J Plankton Res 22:485-497

Engel A (2002) Direct relationship between $\mathrm{CO}_{2}$-uptake and transparent exopolymer particle (TEP) production in natural phytoplankton. J Plankton Res (in press)

Fogg GE (1983) The ecological significance of extracellular products of phytoplankton photosynthesis. Bot Mar 26: 3-14

Fowler SW, Knauer DA (1986) The role of large particles in the transport of elements and organic components through the oceanic water column. Prog Oceanogr 16:147-194

Fuhs WG (1969) Phosphorus content and rate of growth in the diatoms Cyclothella nana and Thalassiosira fluviatilis. J Phycol 5:312-321

Grossart HP (1999) Interactions between marine bacteria and axenic diatoms (Cylindrotheca fusiformis, Nitzschia laevis and Thalassiosira weissflogii) incubated under various conditions in the lab. Aquat Microb Ecol 19:1-11

Grossart HP, Simon M (1997) Formation of macroscopic organic aggregates (lake snow) in a large lake: the significance of transparent exopolymer particles, phytoplankton, and zooplankton. Limnol Oceanogr 42:1651-1659

Grossart HP, Berman T, Simon M, Pohlmann K (1998) Occurrence and microbial dynamics of macroscopic organic aggregates (lake snow) in Lake Kinneret, Israel, in fall. Aquat Microb Ecol 14:59-67

Guillard RRL (1975) Culture of phytoplankton for feeding marine invertebrates. In: Smith WL, Chanley MH (eds) Culture of marine invertebrate animals. Plenum Publishing, New York, p 108-132

Heissenberger A, Leppard GG, Herndl GJ (1996) Relationship between the intracellular integrity and the morphology of the capsular envelope in attached and free living marine bacteria. Appl Environ Microbiol 62:4521-4528

Hellebust JA (1974) Extracellular products. In: Stewart WDP (ed) Algal physiology and biochemistry. Vol. 30. University of California Press, Berkeley, p 838-854

Hoagland K, Rosowski J, Gretz M, Roemaer S (1993) Diatom extracellular polymeric substances: function, fine structure, chemistry, and physiology. J Phycol 29:537-566

Hong Y, Smith WO, White AM (1997) Studies on transparent exopolymer particles (TEP) produced in the Ross Sea (Antarctica) and by Phaeocystis antarctica (Prymnesiophyceae). J Phycol 33:368-376

Johnson KS, Petty RL, Thomsen J (1985) Flow injection analysis of seawater micronutrients. Adv Chem Ser 209:7-30

Kepkay P, Johnson B (1988) Microbial response to organic particle generation by surface coagulation in seawater. Mar Ecol Prog Ser 48:193-198

Kepkay PE, Johnson BD (1989) Coagulation on bubbles allows microbial respiration of oceanic dissolved organic carbon. Nature 338:63-65 
Kiørboe T, Hansen JLS (1993) Phytoplankton aggregate formation: observations of patterns and mechanisms of cell sticking and the significance of exopolymeric material. J Plankton Res 15:993-1018

Kiørboe T, Hansen J, Alldredge AL, Jackson G and 5 others (1996) Sedimentation of phytoplankton during a spring diatom bloom: rates and mechanisms. J Mar Res 54: 1123-1148

Kirchmann D (1993) Statistical analysis of direct counts of microbial abundance. In: Kemp P, Sherr B, Sherr E, Cole J (eds) Handbook of methods in aquatic microbial ecology Lewis Publishers, London, p 117-119

Lancelot C (1983) Factors affecting phytoplankton extracelluler release in the Southern Bight of the North Sea. Mar Ecol Prog Ser 12:115-121

Logan BE, Passow U, Alldredge AL, Grossart HP, Simon M, (1995) Rapid formation and sedimentation of large aggregates is predictable from coagulation rates (half-lives) of transparent exopolymer particles (TEP). Deep-Sea Res Part II 42:203-214

Mague TH, Friberg E, Hughes DJ, Morris I (1980) Extracellular release of carbon by marine phyotplankton; a physiological approach. Limnol Oceanogr 25:262-279

Mari X, Burd A (1998) Seasonal size spectra of transparent exopolymeric particles (TEP) in a coastal sea and comparison with those predicted using coagulation theory. Mar Ecol Prog Ser 163:63-76

Mari X, Kiørboe T (1996) Abundance, size distribution and bacterial colonization of transparent exopolymer particles (TEP) in the Kattegat. J Plankton Res 18:969-986

Mopper K, Zhou J, Ramana KS, Passow U, Dam HG, Drapeau DT (1995) The role of surface-active carbohydrates in the flocculation of a diatom bloom in a mesocosm. Deep-Sea Res Part II 42:47-73

Myklestad S, Haug A, Larsen B (1972) Production of carbohydrates by the marine diatom Chaetoceros affinis var. willei (Gran) Husted II. Preliminary investigation of the extracellular polysaccharides. J Exp Mar Biol Ecol 9:137-144

Myklestad S (1974) Production of carbohydrates by marine planktonic diatoms. I. Comparison of nine different species in culture. J Exp Mar Biol Ecol 15:261-274

Myklestad S, Holm-Hansen O, Varum KM, Volcani BE (1989) Rate of release of extracellular amino acids and carbohydrates from the marine diatom Chaetoceros affinis. J Plankton Res 11:763-774

Myklestad SM (1995) Release of extracellular products by phytoplankton with special emphasis on polysaccharides. Sci Total Environ 165:155-164

Nelson DM, Brzezinski MA (1990) Kinetics of silicic acid uptake by natural diatom assemblages in two Gulf Stream warm-core rings. Mar Ecol Prog Ser 62:283-292

Obernosterer I, Herndl GJ (1995) Phytoplankton extracellular release and bacterial growth: Dependence on the inorganic N:P ratio. Mar Ecol Prog Ser 116:247-257

Parsons TR, Maita Y, Lalli CM (1984) A manual for chemical and biological methods for seawater analysis. Pergamon Press, New York

Passow U (2000) Formation of transparent exopolymer particles, TEP, from dissolved precursor material. Mar Ecol Prog Ser 192:1-11

Passow U, Alldredge AL (1994) Distribution, size, and bacter- ial colonization of transparent exopolymer particles (TEP) in the ocean. Mar Ecol Prog Ser 113:185-198

Passow U, Alldredge AL (1995a) A dye-binding assay for the spectrophotometric measurement of transparent exopolymer particles (TEP). Limnol Oceanogr 40:1326-1335

Passow U, Alldredge AL (1995b) Aggregation of a diatom bloom in a mesocosm: The role of transparent exopolymer particles (TEP). Deep-Sea Res Part II 42:99-109

Passow U, Alldredge AL (1999) Do transparent exopolymer particles (TEP) inhibit grazing by the euphausid Euphausia pacifica? J Plankton Res 21:2203-2217

Passow U, Kozlowski W, Vernet M (1995) Distribution of transparent exopolymer particles (TEP) during summer at a permanent station in Antarctica. Ant J US 30:265-266

Passow U, Shipe RF, Murray A, Pak DK, Brzezinski MA, Alldredge AL (2001) Origin of transparent exopolymer particles (TEP) and their role in the sedimentation of particulate matter. Cont Shelf Res 21:327-346

Penna A, Berluti S, Magnani M (1999) Influence of nutrient ratios on the in vitro extracellular polysaccharide production by marine diatoms from the Adriatic Sea. J Plankton Res 21:1681-1690

Perry MJ (1976) Phosphate utilization by an oceanic diatom in phosphorous limited chemostat culture and in oligotrophic waters of the central North Pacific. Limnol Oceanogr 21: 88-107

Prieto L, Sommer F, Stibor H, Koeve W (2001) Effects of planktonic copepods on transparent exopolymer particles (TEP) abundance and size spectra. J Plankton Res 23:515-525

Riebesell U, Reigstad M, Wassmann P, Noji T, Passow U (1995) On the trophic fate of Phaeocystis pouchetii (Hariot): VI. Significance of Phaeocystis-derived mucus for vertical flux. Neth J Sea Res 33:193-203

Rieman F (1989) Gelatinous phytoplankton detritus aggregates on the Atlantic deep-sea bed. Structure and mode of formation. Mar Biol 100:533-539

Schuster S, Herndl GJ (1995) Formation and significance of transparent exopolymeric particles in the northern Adriatic Sea. Mar Ecol Prog Ser 124:227-236

Sharp J (1977) Excretion of organic matter by marine phytoplankton: do healthy cells do it? Limnol Oceanogr 22: 381-399

Shibata A, Kogure K, Koike I, Ohwada K (1997) Formation of submicron colloidal particles from marine bacteria by viral infection. Mar Ecol Prog Ser 155:303-307

Smith DC, Steward GF, Long RA, Azam F (1995) Bacterial mediation of carbon fluxes during a diatom bloom in a mesocosm. Deep-Sea Res Part II 42:75-97

Staats N, Stal LJ, Mur LR (2000) Exopolysaccharide production by the epipelic diatom Cylindrotheca closterium: effects of nutrient conditions. J Exp Mar Biol Ecol 249:13-27

Stoderegger K, Herndl GJ (1998) Production and release of bacterial capsular material and its subsequent utilization by marine bacterioplankton. Limnol Oceanogr 43:877-884

Stoderegger KE, Herndl GJ (1999) Production of exopolymer particles by marine bacterioplankton under contrasting turbulence conditions. Mar Ecol Prog Ser 189:9-16

Waite AM, Olson RJ, Dam HG, Passow U (1995) Sugar-containing compounds on the cell surfaces of marine diatoms measured using concanavalin A and flow cytometry. J Phycol 31:925-933

Submitted: September 20, 2001; Accepted: January 24, 2002 Proofs received from author(s): May 22, 2002 